\title{
How was the cooking skills and healthy eating evaluation questionnaire culturally adapted to Brazil?
}

\author{
Como o questionário de avaliação das habilidades culinárias \\ e alimentação saudável foi adaptado transculturalmente ao Brasil?
}

Manuela Mika Jomori (https://orcid.org/0000-0003-2294-6692) ${ }^{1}$
Martin Caraher (https://orcid.org/0000-0002-0615-839X) ${ }^{2}$
Greyce Lucy Bernardo (https://orcid.org/0000-0003-0411-012X) ${ }^{1}$
Paula Lazzarin Uggioni (https://orcid.org/0000-0003-2696-0539) ${ }^{1}$
Maria Elena Echevarria-Guanilo (https://orcid.org/0000-0003-0505-9258) ${ }^{3}$
Margaret Condrasky (https://orcid.org/0000-0002-6364-196X) ${ }^{4}$
Rossana Pacheco da Costa Proença (https://orcid.org/0000-0001-6149-8752) ${ }^{1}$

${ }^{1}$ Programa de PósGraduação em Nutrição, Departamento de Nutrição, Universidade Federal de Santa Catarina. R. Delfino Conti S/N, Trindade. 88040370 Florianópolis SC Brasil. manuela.jomori@ufsc.br ${ }^{2}$ Centre for Food Policy, City University of London. London, England.

${ }^{3}$ Departamento de Enfermagem, Universidade Federal de Santa Catarina. Florianópolis SC Brasil. ${ }^{4}$ Food, Nutrition, and Packaging Sciences Department, Clemson University. Clemson SC U.S. Carolina do Sul EUA.

\begin{abstract}
The study described the cross-cultural adaptation process of the American Cooking Skills and Healthy Eating questionnaire to Brazil. Six stages were followed: Translation; Synthesis of translations; Back-translations; Expert Committee; Synthesis of final version; and the Pretest (self-administered online questionnaire in a Brazilian University). Participants responded to the translated questionnaire twice for test-retest. Conceptual, item, semantic, operational and measurement equivalences were evaluated between original and translated questionnaires, as well as the internal consistency and test-retest reliability. Item, conceptual, semantic equivalences between original and Brazilian questionnaires were reached before the Expert Committee stage. Specific cooking techniques and terms were adapted. Forty-eight students answered the questionnaire in the pre-test stage, achieving the operational and measurement equivalences with kappa's agreement from moderate to substantial, and satisfactory to excellent correlations between measures. Only two measures showed low internal consistency. The combination of stages and equivalences approaches used in this cross cultural adaptation study provided lessons for further Nutrition's researches, disclosing the complexity of cooking skills concepts.
\end{abstract}

Key words Translation, Measurement, Equivalence, Culinary, Food preparation
Resumo O estudo descreveu o processo de adaptação transcultural do questionário estadunidense de avaliação das habilidades culinárias e alimentação saudável para o Brasil. Seis estágios foram conduzidos: Tradução; Sintese da tradução; Retrotradução; Comitê de Juízes; Sintese da versão final; e Pré-teste (preenchimento do questionário online). Participantes responderam duas vezes ao questionário traduzido. Equivalências conceitual, do item, semântica, operacional e de mensuração foram avaliadas entre os questionários original e traduzido, bem como a consistência interna e a confiabilidade teste-reteste. Alcançaram-se as equivalências do item, conceitual e semântica entre as versões antes do Comitê de Juizes. Técnicas e termos culinários específicos foram adaptados. Quarenta e oito estudantes responderam o questionário no pré-teste, alcançando equivalências operacional e de mensuração, concordância kappa moderada a substancial, e correlações entre as medidas satisfatórias a excelentes. Duas escalas apresentaram baixa consistência interna. A combinação das abordagens dos estágios e equivalências usadas na adaptação transcultural do questionário proveu lições para futuras pesquisas em Nutrição, revelando a complexidade dos conceitos de habilidades culinárias.

Palavras-chave Tradução, Medida, Equivalência, Culinária, Preparo do alimento 


\section{Introduction}

Cooking skills are noted as an essential element in promoting healthy nutritional habits ${ }^{1-3}$, especially among university students. Barriers are reported by university students to acquiring or developing cooking skills to prepare and eat healthy foods including issues such as: low confidence, limited knowledge of cooking ${ }^{4,5}$, high availability and accessibility of convenience food ${ }^{4,5}$, inadequate kitchen utensils ${ }^{4}$, as well as the lack of time to $\operatorname{cook}^{4,6}$ and money to purchase ingredients ${ }^{6}$.

Furthermore, parameters to evaluate cooking skills related to healthy eating habits are still lacking in the literature $e^{6,78}$. Validated cooking skills questionnaires tended to emphasize the evaluation of nutrition knowledge and food portions, personal norms regarding meal preparation ${ }^{10}$, and motivation to cook of adolescents ${ }^{11}$. One specific questionnaire was developed and validated by researchers from Clemson University in South Carolina, U.S., to evaluate the cooking intervention program Cooking with a Chef (CWC). This questionnaire was chosen because many of its constructs provided the evaluation of aspects related to healthy eating practices in the kitchen, combining Nutrition and Culinary knowledges ${ }^{5,12,13}$. Recently it was validated ${ }^{14}$ to evaluate the Brazilian Program Nutrition and Culinary in the Kitchen $(\mathrm{NCK})^{15}$, but the process of its cross-adaptation to the Brazilian population was not detailed.

Regarding an existing measurement tool in a foreign language and culture, its submission to cross-cultural adaptation for a specific country and culture is necessary ${ }^{16-19}$. Cross-cultural adaptation involves the translation of an existing measurement from its original version to the target language and the process of considering any differences between the source and the target culture so as to maintain equivalence in meaning ${ }^{19}$. To ensure the same effects in the target population like those achieved in the country where the questionnaire was originally developed, authors recommend using the model of equivalences to compare the translated questionnaire to the original one ${ }^{18,20}$. These equivalences consist of: item equivalence ("estimates the same parameters in a latent trait that is being qualitatively and quantitatively measured in the different cultures" ${ }^{20}$ ); conceptual equivalence (explores the domains included and the emphasis placed on these domains about the subject of the measurement, and how they are established in different cultures) ${ }^{16-20}$; semantic equivalence ("is concerned with the transfer of the meaning across languag- es, and with the achieving a similar effect on respondents in different languages" ${ }^{21}$ ), operational equivalence (refers to the using of a similar mode of administration, instructions and measurement methods $)^{16-20}$, and measurement equivalence (related to the psychometric proprieties of the questionnaire) $)^{16-20}$.

Moreover, six stages to cross-cultural adaptation of healthy-related self-reported questionnaires are recommended, such as: 1) Translation (translations of the original version into the language of the target culture),2) Synthesis of translations (process of synthesize the results of the translations), 3) Back-translations (translation of the synthesis of questionnaires back into the original language), 4) Expert Committee (review of all the translations until reaching a consensus on any discrepancy), 5) Synthesis of final Brazilian Portuguese version (consolidation of a final version after a review of the consensus version), and 6) Pre-test (application of the final version in subjects from the target setting) $)^{16-19}$.

Articles about cross-cultural adaptation of nutrition-related questionnaires have summarily described their procedures in the method section but focused on the results of validation process $^{14,20-22}$. Moreover, most of them undertook few stages of cross-cultural adaptation, generally until the back-translation stage, so that they evaluated basically the idiomatic aspects of the translation ${ }^{20-22}$. Two studies added the pre-test stage with at least 30 participants and followed all recommended stages ${ }^{20,22}$ but no one detailed the cross-cultural process. Thus, the purpose of the present study is to describe the cross-cultural adaptation process of questionnaire to evaluate cooking skills and healthy eating of Brazilian university students, providing some lessons for Nutrition's research.

\section{Methods}

\section{Measures}

The cooking skills and healthy eating evaluation questionnaire was developed and validated to evaluate the Cooking with a Chef intervention program by Clemson University's researchers ${ }^{12,13}$. This program was based on the connection of Nutrition and Culinary knowledges, aiming to improve eating behaviors with a culinary intervention $^{6,12,13}$.

The Cooking with a Chef (CWC) questionnaire was validated for use in Brazil ${ }^{14}$. The ques- 
tionnaire consists of six scales, one knowledge evaluation section, and a short index, with a total of 64 items, as described in Chart 1.

The higher the value obtained from means of AAFV (Availability and Accessibility of Fruits and Vegetable Index), CA (Cooking Attitude), CB (Cooking Behaviour), SEPC (Self-Efficacy in Produce Consumption), SEC (Cooking Self-Efficacy), SECT (Self-Efficacy in Using Basic Cooking Techniques), SEFVS (Self-Efficacy in Using Fruits, Vegetables and Seasonings) measures, the higher the cooking skills were considered. For CTT (Knowledge in Cooking Terms and Techniques Evaluation) measure, if participants answered correctly $\geq 75 \%$ of the items ( $\geq 6$ items), they were classified as having high level of knowledge and those who answered $\leq 60 \%$ ( $\leq 5$ items), were classified as having low level of knowledge ${ }^{12,14}$.

\section{Participants}

Students enrolled in undergraduate programs at Federal University of Santa Catarina (UFSC), Brazil in 2015 were recruited at an event that took place on the first day of class for the semester, classrooms and university cafeteria's lines, where about 1.000 folders were distributed with questionnaire websites address and URL code reader ( $Q R$ code) during 2 months. The first students who answered the questionnaire were selected to the study until the sample reached the minimum required, according to the following inclusion criteria: students enrolled in the first year in undergraduate programs at UFSC in 2015, 16 years or older. Those enrolled before 2015 , in postgraduate as well as in online courses were excluded.

Chart 1. Description of the evaluation questionnaire of Cooking with a Chef (CWC) Programme regarding sources of measurements and items composition.

\begin{tabular}{|c|c|c|c|}
\hline Measures & Description & Items $(64)$ & Responses \\
\hline $\begin{array}{l}\text { Availability and } \\
\text { Accessibility of Fruits and } \\
\text { Vegetables index (AAFV) }\end{array}$ & $\begin{array}{l}\text { The AAFV measured the availability } \\
\text { of fruits and vegetable over the past } \\
\text { week }\end{array}$ & 7 & $\begin{array}{l}\text { Yes/no questions, scored as } 1 \\
\text { or } 2 \text {, respectively }\end{array}$ \\
\hline $\begin{array}{l}\text { Cooking Attitude scale } \\
\text { (CA) }\end{array}$ & $\begin{array}{l}\text { CA measured how respondents } \\
\text { felt about cooking [e.g. (dis)liking } \\
\text { cooking, try new recipes, cooking } \\
\text { is(not) tiring, (un)healthy, affordable, } \\
\text { etc] }\end{array}$ & 7 & $\begin{array}{l}\text { Five-point Likert responses } \\
\text { (from "strongly disagree" to } \\
\text { "strongly agree") and } 4 \text { of the } \\
\text { items had statements with } \\
\text { reverse wording thus reversed } \\
\text { scores }\end{array}$ \\
\hline $\begin{array}{l}\text { Cooking Behavior scale } \\
\text { (CB) }\end{array}$ & $\begin{array}{l}\text { CB measured the frequency of } \\
\text { cooking activities (e.g. cooking from } \\
\text { basic ingredients and/or convenience } \\
\text { foods and/or leftovers) }\end{array}$ & 11 & $\begin{array}{l}\text { Responses options: "not at all", } \\
\text { "1 to } 2 \text { times a month", “once } \\
\text { a week", “several times a week", } \\
\text { and "about every day". }\end{array}$ \\
\hline $\begin{array}{l}\text { Produce Consumption } \\
\text { Self-Efficacy scale(SEPC) }\end{array}$ & $\begin{array}{l}\text { SEPC measured the degree } \\
\text { of confidence in meeting the } \\
\text { government's three recommendations } \\
\text { for the consumption of fruits and } \\
\text { vegetables daily }\end{array}$ & 3 & $\begin{array}{l}\text { Five-point Likert scale (from } \\
\text { "not at all confident" to } \\
\text { "extremely confident"). }\end{array}$ \\
\hline $\begin{array}{l}\text { Cooking Self-Efficacy scale } \\
\text { (SEC) }\end{array}$ & $\begin{array}{l}\text { SEC measured the degree of } \\
\text { confidence in performing basic } \\
\text { activities regarding meal preparation }\end{array}$ & 6 & $\begin{array}{l}\text { Five-point Likert scale (from } \\
\text { "not at all confident" to } \\
\text { "extremely confident"). }\end{array}$ \\
\hline $\begin{array}{l}\text { Self-Efficacy for Using } \\
\text { Cooking Techniques } \\
\text { scale(SECT) }\end{array}$ & $\begin{array}{l}\text { SECT measured the degree of } \\
\text { confidence in performing specific } \\
\text { cooking techniques. }\end{array}$ & 12 & $\begin{array}{l}\text { Five-point Likert scale (from } \\
\text { "not at all confident" to } \\
\text { "extremely confident"). }\end{array}$ \\
\hline $\begin{array}{l}\text { Self-Efficacy for Using } \\
\text { Fruits, Vegetables and } \\
\text { Seasonings scale(SEFVS) }\end{array}$ & $\begin{array}{l}\text { SEFVS measured the degree of } \\
\text { confidence in using fruits, vegetables, } \\
\text { seasonings such as herbs and spices } \\
\text { when cooking. }\end{array}$ & 9 & $\begin{array}{l}\text { Five-point Likert scale (from } \\
\text { "not at all confident" to } \\
\text { "extremely confident"). }\end{array}$ \\
\hline $\begin{array}{l}\text { Knowledge on Cooking } \\
\text { Terms and Techniques } \\
\text { evaluation }(\mathrm{CTT})\end{array}$ & $\begin{array}{l}\text { CTT measured the level of cooking } \\
\text { knowledge }\end{array}$ & 8 & $\begin{array}{l}\text { Four options of responses. } \\
\text { where the correct answer } \\
\text { scores } 1 \text { point }\end{array}$ \\
\hline
\end{tabular}

Source: Jomori et al. ${ }^{14}$. 
A minimum of 30 participants were required for the pre-test stage as recommended in the literature $^{17,18,23}$, considering the aim is to verify the necessity of changes and not for confirmation with statistical significance and there is no recommendation to a bigger sample to pre-test stage Informed consent was obtained from all participants. No incentive was given to the participants.

\section{Study design and Data Collection}

The U.S. Cooking skills and Healthy Eating questionnaire was authorized by its authors to be cross-adapted and used in Brazil.

The questionnaire was subject to six stages as recommended for the cross-cultural adaptation process $^{16,18}$ : I-Translation, II-Synthesis of Translation, III-Back-Translation, IV-Expert Committee, V-Synthesis of Final Translation and VI-Pretest.

In stage I, two translations of the questionnaire from English into two Brazilian Portuguese were produced independently by bilingual translators as recommended by researchers ${ }^{16-18}$.

This was followed by the Synthesis of translations stage (II), where the translators plus the main researcher formulated a single Brazilian Portuguese version. This version was then, translated into two English versions independently by bilingual translators in the Back-translation stage (III). All items from each back-translated version were paired with their respective items from the original version in a random sequence for comparison separately by each translator without knowing which item was from original or back-translated version in a blind analysis. One of the translators compared the items pairs from the other back-translator and vice versa. They evaluated each pair by selecting a response (one of the four options) which rated the degree of change in between the original version and the back-translated items, as follows: (1) not altered, (2) little altered, (3) much altered, (4) entirely altered ${ }^{23}$.

After this, the main researcher and five Brazilian dietitians with knowledge of the English language discussed the main differences found at the evaluations of the comparisons listed above, as well as the difficulties at the translations. They consulted the author of the questionnaire to check parts of the back-translations, defining the second synthesis version in Brazilian Portuguese $\mathrm{e}^{16,17}$.

A copy of the second synthesis of the Brazilian Portuguese version and definitions of some terms were submitted to members of the Expert
Committee (stage IV) by e-mail previously to the Consensus Workshop ${ }^{25}$. Ten dietitians (one with $\mathrm{PhD}$ about validating questionnaires, two participated in the translation and back-translation stages, three were dietitians from stage III), a methodologist (nurse with PhD about cross-cultural adaptation and validation of questionnaires) and three were students from the Undergraduate Nutrition Program at UFSC attended to the stage IV.

In this workshop, the main researcher explained the procedures used to produce the second synthesis of the Brazilian Portuguese version and asked members to discuss any doubts they had regarding each item on the questionnaire. Divergences found in the comparison of back-translations with the original version were pointed out when necessary. Members evaluated the items and discussed problems with understanding them until a consensus was reached.

The synthesis of the final Brazilian Portuguese version of the questionnaire was produced $^{14}$ (stage V) and was available in an online format August of 2015, by Google Forms to be accessed and self-administrated by students enrolled at the first year of university on public websites (stage VI). If a question did not receive a response, the respondent could not continue answering the questions that followed. Data collection was carried out until the minimum of participants to pre-test was achieved at which time the questionnaire was closed at the website.

Participants evaluated the format of questions and instructions, response options, as well as made notes of any difficulties they experienced in their comprehension of the questionnaire ${ }^{16-18,24}$. This evaluation was conducted with four closed questions ('yes/no/partially') regarding understanding/clarity. Each question had a comment space in which students could supply reasons for their answers. The students were asked to fill in their start and end times. Data such as e-mail for contact, gender, age and academic major were also collected.

After two weeks from the first administration, the same students that agreed to participate on the pre-test were invited to answer the questionnaire a second time in order to complete the test-retest evaluation. E-mails were sent to participants for accessing and responding to the online questionnaire. The interval between self-administrations of 2 to 4 weeks was considered acceptable to minimize those participants recall responses provided at the first self-administration or of any change of behaviors ${ }^{26}$. 


\section{Data analysis}

Mean and standard deviations for age and time of answering, as well as relative frequency of gender and academic major data were shown to characterize the participants.

In all stages, equivalences between the original and the translated questionnaires were evaluated based on existing recommendations ${ }^{17-19}$, as described in Figure 1.

The conceptual equivalence were evaluated by exploring definitions and concepts related to cooking skills, and how they were established in both U.S. and Brazilian cultures under a previous literature review ${ }^{8}$. This equivalence was verified in most of stages to achieve the same message intent for the specific terms and expressions as taken from the original version to become appropriate for Brazilian students ${ }^{16,18,19}$.

For achieving the item equivalence, the same parameters in a latent trait were quantitatively measured ${ }^{18,19}$ in back-translation and pre-test stages (III and VI). In stage III, the percentage of agreement between back-translation versions and the original version was calculated by comparing item pairs ${ }^{18,19}$. Regarding answers obtained in stage VI, at least $90 \%$ adequacy was required ${ }^{18}$ in relation to ease of understanding and filling out the items. In remaining stages, parameters were qualitatively measured to achieve item equivalence.

The semantic equivalence was assessed in all stages to achieve similar effects on respondents via different languages, by using the referential meaning (denotative) and general meaning (connotative) in each stage (Figure 1). Referential meaning is related to the literal correspondence between the original and translated item. General meaning is a contrasting correspondence between the original and translated versions which transcends the literalness of the words and encompasses more subtle aspects, such as the impact that a term has within the cultural context of the target population $^{18}$.

The semantic equivalence also involves the idiomatic equivalence, which consists of verifying items of difficult translations from the original instrument. These were substituted for equivalent expressions without modifying their meaning (referential meaning), as well as the experiential one, which evaluates whether a determined item can be applied in a new culture (general meaning $)^{18,19}$. In the Expert Committee (Stage IV), $\geq 2 / 3$ of agreement among participants was required for consensus ${ }^{25}$ on each item evaluated to achieve conceptual, item and semantic equivalences.

For the operational equivalence the format, instructions, ways of responding, and techniques in constructing measures for the questionnaire were compared the original one $\mathrm{e}^{18,19}$. When respondents reported that they did not understand or partially understood a question in the pre-test, the reasons they provided were verified and used in considering changes for the flagged items.

The measurement equivalence refers to reaching the acceptable levels of the translated questionnaire in terms of psychometric proprieties (i.e. reliability, responsiveness, validity $)^{18,19}$. Data from pre-test were submitted to the internal consistency reliability analysis (Figure 1). Cronbach's alpha coefficient was obtained to verify the scale's internal consistency, which yielded a satisfactory value of $0,70^{26}$.

For test-retest of the questionnaire, the correlated agreement reliability was calculated using Cohen's unweighted kappa statistic for the dichotomous scale - AAFV. The parameters adopted were as follows: no agreement $(k<0)$, slight $(0 \leq \mathrm{K}<0,21)$, weak $(0,21 \leq \mathrm{K}<0,41)$, moderate $(0,41 \leq \mathrm{K}<0,61)$, substantial $(0,61 \leq \mathrm{K}<0,81)$, almost perfect $(0,81 \leq K \leq 1,00)$, and $p$ value $<0,05$ for significant agreement ${ }^{26}$. For continuous variables (from measures CA, CB, SEPC, SEC, SECT, SEFVS, CTT), the correlation between means of each interval scale from the two self-administrations were obtained by using Intraclass Correlation (ICC) coefficient, adopting two-way random effects model. The stability's coefficient varies from 0 to 1 , and ICC $<0,4$ was considered as poor; $0,4 \leq$ ICC $<0.75$ as satisfactory to good; ICC $\geq 0,75$ as excellent, while considering $\mathrm{p}$ value $<0,05$ for significant correlation ${ }^{27}$.

The calculations were made using the Statistical Package for the Social Sciences SPSS ${ }^{\circledR}$ version 18.0.

\section{Ethical considerations}

This study was previously approved by the University of Santa Catarina's Ethical Committee on Human Research and all participants showed their informed consent. 


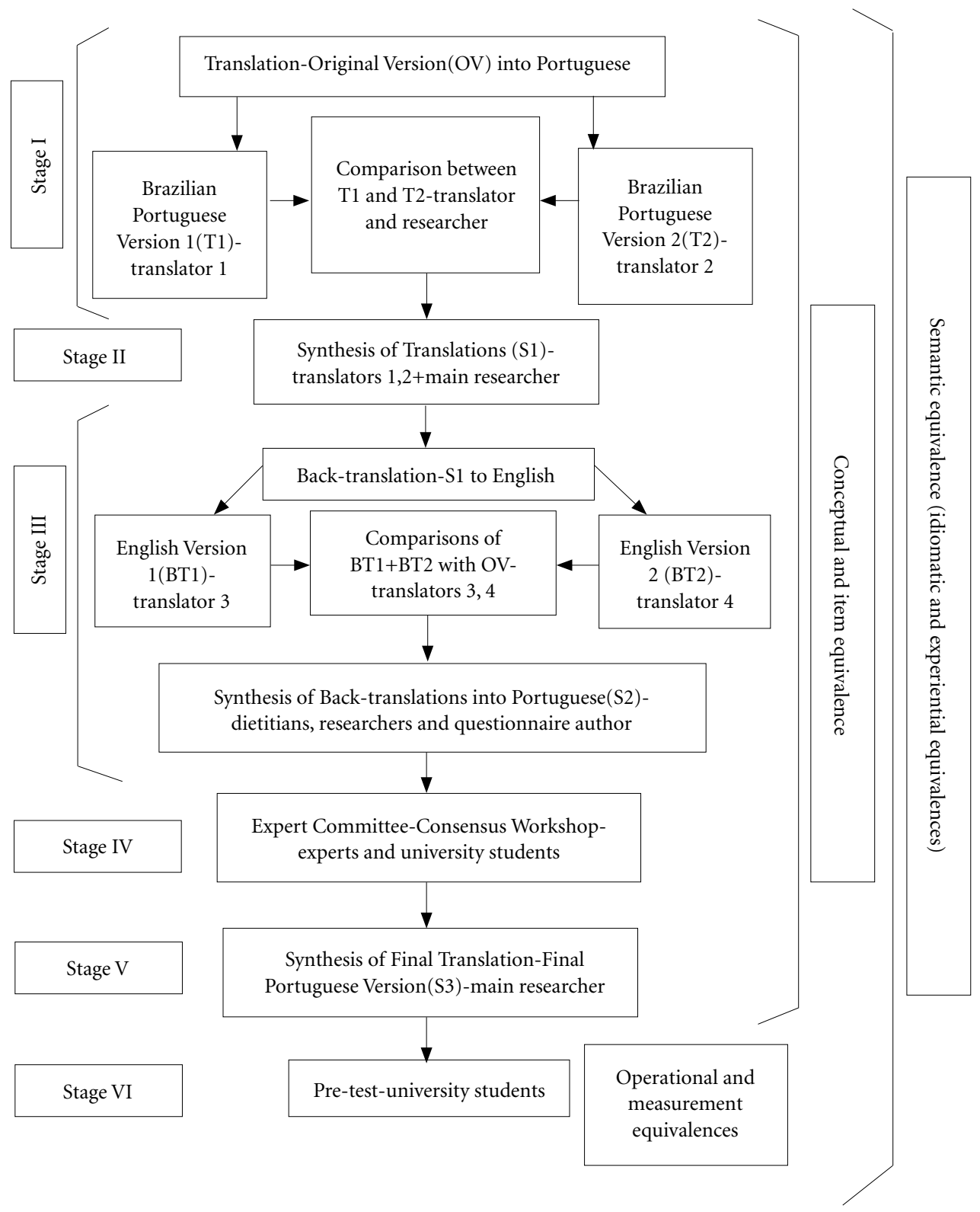

Figure 1. Stages and equivalences of the Brazilian cross-cultural adaptation of a cooking skills questionnaire.

$\mathrm{OV}=$ Original Version $/ \mathrm{T} 1=$ First Portuguese translation $/ \mathrm{T} 2=$ Second Portuguese translation/ S1=First synthesis of translations in Portuguese / BT1=Firstback-translation/ BT2= Second back-translation/S2=Second synthesis of translations in Portuguese/ S3=Synthesis of final translation/

Translator 1 - bilingual professional Brazilian Portuguese native-speaking / Translator 2 - bilingual dietitian with knowledge of the content of the measurement / Translator 3 - bilingual professional U.S. English native-speaking / Translator 4 - bilingual dietitian with knowledge of the content of the measurement.

Source: Jomori ${ }^{28}$. 


\section{Results}

\section{What are the differences between the original and the translated questionnaire?}

Conceptual, item and semantic equivalences were achieved in the Brazilian Portuguese version as summarized in Chart 2.

In the Availability and Accessibility of Fruits and Vegetables measure (AAFV), the American term "fruit juice 100\%", where it is recommended to be consumed as a portion of fruit ${ }^{2}$, was found to be unusual in Brazil. Thus, some examples were added in brackets to achieve semantic (experiential) equivalence, considering the referential meaning of the expression as well as the conceptual equivalence to the original meaning.
In the question "In the last week, were vegetables in the refrigerator prepared so they could be readily used in a meal?", “...used in a meal?" led to two meanings for Brazilians: prepared or eaten in a meal. The author of the original questionnaire clarified that it meant "readily eaten". Furthermore, a 'meal' in Brazil can be a lunch, a dinner or a snack ${ }^{3}$. Then, the meals were specified in the adapted questionnaire as lunch or dinner.

In the Cooking Attitude scale (CA) low equivalences were verified in the original terms "affordable" and "healthfully". The word "affordable" was back-translated to "accessible" in the first back-translation, which rendered two meanings: one regarded inexpensive goods or being within budget ("affordable"), and the other means achievable or ease to get.

Chart 2. Adaptation of main items of the cooking skills questionnaire to Brazilian Portuguese in different stages, according to some of its measures, conceptual, item and semantic equivalences with the original questionnaire.

\begin{tabular}{|c|c|c|c|}
\hline \multirow[b]{2}{*}{ Original items } & \multicolumn{3}{|c|}{$\begin{array}{c}\text { Conceptual, item and semantic (idiomatic and experiential) } \\
\text { equivalent terms/expressions }\end{array}$} \\
\hline & $\begin{array}{c}\text { Stages I and } \\
\text { II - Translation } \\
\text { and Synthesis of } \\
\text { translations }\end{array}$ & Stage III - Back-translation & Stage IV - Expert Committee \\
\hline \multicolumn{4}{|l|}{ AAFV Index } \\
\hline $\begin{array}{l}\text { "pure (100\%) } \\
\text { fruit juice" }\end{array}$ & $\begin{array}{l}\text { "100\% natural fruit } \\
\text { juice" (suco de fruta } \\
100 \% \text { natural) }\end{array}$ & $\begin{array}{l}\text { " } 100 \% \text { natural fruit juice" - } \\
\text { 'Much altered' (Evaluation } \\
\text { of BT1) and 'Little altered' } \\
\text { (Evaluation of BT2) compared } \\
\text { to the original item }\end{array}$ & $\begin{array}{l}\text { " } 100 \% \text { natural fruit juice } \\
\text { (homemade fruit juice, including } \\
\text { fruit pulp or ready-to-drink whole } \\
\text { fruit juice)" (preparado em casa ou } \\
\text { que inclui polpa de fruta ou suco de } \\
\text { fruta integral pronto para consumo) } \\
\text { - specified to usual fruit juices in } \\
\text { Brazil }\end{array}$ \\
\hline $\begin{array}{l}\text { "...on the } \\
\text { kitchen counter } \\
\text { or somewhere in } \\
\text { the open?" }\end{array}$ & $\begin{array}{l}\text { "...visible on the } \\
\text { conter or in another } \\
\text { place of the kicthen" } \\
\text { (visiveis em cima do } \\
\text { balcão ou em outro } \\
\text { lugar na cozinha) }\end{array}$ & $\begin{array}{l}\text { "...visible on top of the } \\
\text { counter or in another place in } \\
\text { the kitchen" - 'Much altered' } \\
\text { (Evaluation of BT1) and 'Little } \\
\text { altered' (Evaluation of BT2) } \\
\text { compared to the original item }\end{array}$ & $\begin{array}{l}\text { “...visible in any place in the } \\
\text { kicthen” (visiveis em algum lugar } \\
\text { na cozinha) - adaptated to a } \\
\text { general meaning }\end{array}$ \\
\hline $\begin{array}{l}\text { "...cut up fresh } \\
\text { vegetables on } \\
\text { the front of the } \\
\text { refrigerator as a } \\
\text { snack"a }\end{array}$ & $\begin{array}{l}\text { "...cut fresh vegetables } \\
\text { visible in the } \\
\text { refrigerator for a } \\
\text { snack" (vegetais frescos } \\
\text { picados na geladeira } \\
\text { para um lance) }\end{array}$ & $\begin{array}{l}\text { "...freshly cut vegetables visible } \\
\text { in the refrigerator for a snack" } \\
\text { - 'Much altered' (Evaluation } \\
\text { of BT1) and 'Little altered' } \\
\text { (Evaluation of BT2) compared } \\
\text { to the original item }\end{array}$ & $\begin{array}{l}\text { “... vegetables and greens ready to } \\
\text { be easily used in a snack” (verduras } \\
\text { e legumes prontos para serem } \\
\text { facilmente utilizados no lanche) - } \\
\text { adaptated to a general meaning }\end{array}$ \\
\hline $\begin{array}{l}\text { "...prepared so } \\
\text { they could be } \\
\text { readily used in a } \\
\text { meal" }\end{array}$ & $\begin{array}{l}\text { “...ready to be easily } \\
\text { used in a meal" } \\
\text { (prontos para serem } \\
\text { facilmente utilizadas } \\
\text { em uma refeição) }\end{array}$ & $\begin{array}{l}\text { “...that were ready to be } \\
\text { easily used in a meal" - 'Much } \\
\text { altered' (Evaluation of BT1) } \\
\text { and 'Little altered' (Evaluation } \\
\text { of BT2) compared to the } \\
\text { original item }\end{array}$ & $\begin{array}{l}\text { “... ready to be easily eaten in the } \\
\text { lunch or dinner)" (prontos para } \\
\text { serem facilmente consumidos no } \\
\text { almoço ou jantar) - specified to } \\
\text { usual meals in Brazil }\end{array}$ \\
\hline
\end{tabular}


Chart 2. Adaptation of main items of the cooking skills questionnaire to Brazilian Portuguese in different stages, according to some of its measures, conceptual, item and semantic equivalences with the original questionnaire.

\begin{tabular}{|c|c|c|c|}
\hline \multirow[b]{2}{*}{ Original items } & \multicolumn{3}{|c|}{$\begin{array}{c}\text { Conceptual, item and semantic (idiomatic and experiential) } \\
\text { equivalent terms/expressions }\end{array}$} \\
\hline & $\begin{array}{l}\text { Stages I and } \\
\text { II - Translation } \\
\text { and Synthesis of } \\
\text { translations }\end{array}$ & Stage III - Back-translation & Stage IV - Expert Committee \\
\hline \multicolumn{4}{|l|}{ CA Scale } \\
\hline "affordable" & "accessible" (acessíveis) & $\begin{array}{l}\text { "accessible" - 'Little altered' } \\
\text { (Evaluation of BT1) and } \\
\text { 'Much altered'(Evaluation } \\
\text { of BT2 which explained the } \\
\text { difference between accessible } \\
\text { and affordable) compared to } \\
\text { the original item }\end{array}$ & $\begin{array}{l}\text { "suitable to someone’s budget" } \\
\text { (acessíveis financeiramente) - } \\
\text { adapted to an inexistent word in } \\
\text { Brazil }\end{array}$ \\
\hline 'healthfully" & $\begin{array}{l}\text { "healthier way" } \\
\text { (de maneira mais } \\
\text { saudável) }\end{array}$ & $\begin{array}{l}\text { "more healthfully" - 'Much } \\
\text { altered' (Evaluation of BT1) } \\
\text { and 'Unaltered' (Evaluation of } \\
\text { BT2) compared to the original } \\
\text { item }\end{array}$ & $\begin{array}{l}\text { "healthier way" (de maneira } \\
\text { mais saudável) - adapted to an } \\
\text { inexistent word in Brazil }\end{array}$ \\
\hline \multicolumn{4}{|l|}{ CB Scale } \\
\hline $\begin{array}{l}\text { "bagged salad, } \\
\text { prepared } \\
\text { mashed } \\
\text { potatoes" }\end{array}$ & $\begin{array}{l}\text { "ready-to-eat salad, } \\
\text { ready mashed potatoes" } \\
\text { (salada pronta para } \\
\text { consumo, purê de } \\
\text { batatas pronto) }\end{array}$ & $\begin{array}{l}\text { "ready-to-eat salad, ready- } \\
\text { made mashed potatoes" - - } \\
\text { 'Much altered' (Evaluation } \\
\text { of BT1) and 'Little altered' } \\
\text { (Evaluation of BT2) compared } \\
\text { to the original item }\end{array}$ & $\begin{array}{l}\text { "ready-to-eat leaves, canned corn" } \\
\text { (salada pronta para consumo, milho } \\
\text { em conserva) - examples more } \\
\text { usual in Brazil than the original } \\
\text { ones }\end{array}$ \\
\hline $\begin{array}{l}\text { "leftovers from } \\
\text { a meal away } \\
\text { from home in a } \\
\text { new dish" }\end{array}$ & $\begin{array}{l}\text { "leftovers from a } \\
\text { meal purchased away } \\
\text { from home to create } \\
\text { a new dish" (sobras de } \\
\text { uma refeição pronta } \\
\text { comprada fora de casa } \\
\text { para criar um novo } \\
\text { prato) }\end{array}$ & $\begin{array}{l}\text { "leftover food from a ready } \\
\text { meal bought away from home } \\
\text { to create a new dish" - 'Much } \\
\text { altered' (Evaluation of BT1) } \\
\text { and 'Unaltered' (Evaluation of } \\
\text { BT2) compared to the original } \\
\text { item }\end{array}$ & $\begin{array}{l}\text { "leftovers from a ready meal } \\
\text { purchased away from home to } \\
\text { create a new dish" (sobras de uma } \\
\text { refeição pronta comprada fora de } \\
\text { casa para fazer um novo prato) - } \\
\text { specified to usual expressions in } \\
\text { Brazil }\end{array}$ \\
\hline \multicolumn{4}{|l|}{ SECP Scale ${ }^{\mathrm{b}}$} \\
\hline $\begin{array}{l}\text { "9 half-cup } \\
\text { servings of fruits } \\
\text { and vegetables"a }\end{array}$ & $\begin{array}{l}\text { "9 half portions of } \\
\text { fruits and vegetables" } \\
{[9 \text { metades }(1 / 2) \text { de }} \\
\text { porções de frutase } \\
\text { vegetais] }\end{array}$ & $\begin{array}{l}\text { "9/2 half }(1 / 2) \text { servings" - } \\
\text { 'Little altered' (Evaluation } \\
\text { of BT1) and 'Much altered' } \\
\text { (Evaluation of BT2 which } \\
\text { noted that 'cup' was lack in } \\
\text { one of the options)compared } \\
\text { to the original item }\end{array}$ & $\begin{array}{l}\text { "3 servings of fruits and } 3 \text { servings } \\
\text { of vegetables and greens" ( } 3 \\
\text { porções de frutas e } 3 \text { de legumes e } \\
\text { verduras) - adapted to Brazilian } \\
\text { food recommendations }\end{array}$ \\
\hline \multicolumn{4}{|l|}{ SEC Scale } \\
\hline "fresh salsa" & 'sauce' (molho) & $\begin{array}{l}\text { 'sauce' - 'Little altered' } \\
\text { (Evaluation of BT1) and } \\
\text { 'Much altered' (Evaluation } \\
\text { of BT2 which explained } \\
\text { that 'salsa' was defined as a } \\
\text { 'Mexican sauce' usually eaten } \\
\text { in U.S.) compared to the } \\
\text { original item }\end{array}$ & $\begin{array}{l}\text { "salsa vinagrete" (molho } \\
\text { vinagrete)-adapted to a popular } \\
\text { sauce in Brazil eaten with barbecue } \\
\text { meat most of the time, made with } \\
\text { fresh tomatoes, green peppers, } \\
\text { onions, vinegar, olive oil and salt }\end{array}$ \\
\hline
\end{tabular}


Chart 2. Adaptation of main items of the cooking skills questionnaire to Brazilian Portuguese in different stages, according to some of its measures, conceptual, item and semantic equivalences with the original questionnaire.

\begin{tabular}{|c|c|c|c|}
\hline \multirow[b]{2}{*}{ Original items } & \multicolumn{3}{|c|}{$\begin{array}{c}\text { Conceptual, item and semantic (idiomatic and experiential) } \\
\text { equivalent terms/expressions }\end{array}$} \\
\hline & $\begin{array}{l}\text { Stages I and } \\
\text { II - Translation } \\
\text { and Synthesis of } \\
\text { translations }\end{array}$ & Stage III - Back-translation & Stage IV - Expert Committee \\
\hline \multicolumn{4}{|l|}{ SECT Scale } \\
\hline "simmering" & $\begin{array}{l}\text { "cooking over a low } \\
\text { heat" (cozinhar em } \\
\text { fogo brando) }\end{array}$ & $\begin{array}{l}\text { "boil on a low heat" - 'Much } \\
\text { altered' (Evaluation of BT1) } \\
\text { and 'Unaltered' (Evaluation of } \\
\text { BT2) compared to the original } \\
\text { item }\end{array}$ & $\begin{array}{l}\text { "cooking over a low heat" (cozinhar } \\
\text { em fogo brando) - adapted to an } \\
\text { inexistent word in Brazil }\end{array}$ \\
\hline "deep frying” & $\begin{array}{l}\text { "frying in a huge } \\
\text { amount of oil" (fritar } \\
\text { com muito óleo) }\end{array}$ & $\begin{array}{l}\text { "fry with a lot of oil" - 'Much } \\
\text { altered'(Evaluation of BT1) and } \\
\text { 'Unaltered' (Evaluation of BT2) } \\
\text { compared to the original item }\end{array}$ & $\begin{array}{l}\text { "frying (in a huge amount of oil)" } \\
\text { (fritar [com muito óleo]) - adapted } \\
\text { to more usual expression in Brazil }\end{array}$ \\
\hline "stir-frying" & "braising" (refogar) & $\begin{array}{l}\text { "sauté" - 'Much altered' } \\
\text { (Evaluation of BT1) and 'Little } \\
\text { altered' (Evaluation of BT2) } \\
\text { compared to the original item }\end{array}$ & $\begin{array}{l}\text { "braising" (refogar) - adapted to a } \\
\text { different and more usual word in } \\
\text { Brazil }\end{array}$ \\
\hline "grilling" & "broiling" (grelhar) & $\begin{array}{l}\text { "grill" - 'Much altered' } \\
\text { (Evaluation of BT1) and } \\
\text { 'Unaltered' (Evaluation of BT2) } \\
\text { compared to the original item }\end{array}$ & $\begin{array}{l}\text { "barbecuing in a pan" (chapear) } \\
\text { - also called as "grilling" in Brazil, } \\
\text { but it is not in a grill }\end{array}$ \\
\hline "baking" & $\begin{array}{l}\text { "baking in the oven" } \\
\text { (assar no forno) }\end{array}$ & $\begin{array}{l}\text { "roast/bake in an oven" - } \\
\text { 'Much altered'(Evaluation } \\
\text { of BT1) and 'Little altered' } \\
\text { (Evaluation of BT2) compared } \\
\text { to the original item }\end{array}$ & $\begin{array}{l}\text { "baking in the oven" (assar em } \\
\text { forno) - 'baking' and 'roasting' } \\
\text { present the same meaning in } \\
\text { Brazil, so, they were differentiated } \\
\text { by indicating cooking equipment }\end{array}$ \\
\hline "roasting" & $\begin{array}{l}\text { "roasting in flame } \\
\text { (barbecue pit or grill)" }\end{array}$ & $\begin{array}{l}\text { "baking flame (barbecue } \\
\text { or grill)" - 'Much altered' } \\
\text { (Evaluation of BT1) and } \\
\text { 'Entirely altered'(Evaluation } \\
\text { of BT2 which mentioned } \\
\text { that barbecuing and grilling } \\
\text { are diferent from baking and } \\
\text { roasting) compared to the } \\
\text { original items }\end{array}$ & $\begin{array}{l}\text { "barbecuing in a grill" (assar } \\
\text { na churrasqueira) - 'baking' } \\
\text { and 'roasting' present the same } \\
\text { meaning in Brazil, so, they were } \\
\text { differentiated by indicating } \\
\text { cooking equipment }\end{array}$ \\
\hline "microwaving" & $\begin{array}{l}\text { "cooking in the } \\
\text { microwave" (cozinhar } \\
\text { no micro-ondas) }\end{array}$ & $\begin{array}{l}\text { "cook in a microwave oven" } \\
\text { - 'Much altered'(Evaluation } \\
\text { of BT1) and 'Unaltered' } \\
\text { (Evaluation of BT2) compared } \\
\text { to the original item }\end{array}$ & $\begin{array}{l}\text { "using the microwave oven" } \\
\text { (utilizar o forno micro-ondas) - } \\
\text { adapted to an inexistent word in } \\
\text { Brazil }\end{array}$ \\
\hline \multicolumn{4}{|l|}{ SEFVS Scale } \\
\hline $\begin{array}{l}\text { "spinach", } \\
\text { "peach", "basil" } \\
\text { and "thyme" }\end{array}$ & $\begin{array}{l}\text { "spinach" } \\
\text { (espinafre),"peach" } \\
\text { (pêssego), "basil" } \\
\text { (manjericão) and } \\
\text { "thyme" (tomilho) }\end{array}$ & $\begin{array}{l}\text { "spinach", "peach", "basil" and } \\
\text { "thyme" - 'Unaltered" and } \\
\text { 'Little altered' compared to } \\
\text { the original item }\end{array}$ & $\begin{array}{l}\text { "pea" (ervilha), "orange" (laranja), } \\
\text { "parsley" (salsinha) and "chives" } \\
\text { (cebolinha), respectively - examples } \\
\text { more common in Brazil than the } \\
\text { original ones }\end{array}$ \\
\hline
\end{tabular}

Source: Jomori ${ }^{28}$. 
Thus, this term was complemented and adapted as "suitable to someone's budget". The term "healthfully" was not translated literally into Brazilian Portuguese in the first stage but replaced with "healthier way" (de maneira mais saudável) in the synthesis of translations to find a general meaning and achieve the semantic and idiomatic equivalences.

The term "half-cup", presented in the Self-Efficacy Produce Consumption scale (SEPC) as a known portion of food in U.S. (established volumetrically 8 fluid ounces) ${ }^{2}$ could not be literally translated as one-half measure of a kitchen utensil or unit of food to Brazilian Portuguese. This term had been distorted during evaluation in stage III (Back-translation) as 'little altered' as well as 'much altered' in the evaluations between back-translated and original versions of the questionnaire. The semantic equivalence was not achieved here considering that, for U.S. dietitians, it clearly refers to a standardized quantitative measurement of certain food portions while among Brazilians, and even Brazilian dietitians, this measurement is not so exact and is standardized. In Brazil the "cup" can rate different amount in grams or milliliters of ingredients. From this, "half cup" was adapted as the exact number of portions recommended in Brazil ${ }^{3}$. Then, it achieved the conceptual and idiomatic equivalences to the original expression.

In the Self-Efficacy in using Cooking Techniques scale (SECT), translators from stage I found no specific terms for the words "simmering" and "microwaving" in Brazilian Portuguese language. Looking towards the idiomatic equivalences, they were translated to Portuguese language as "cooking in a low heat" (cozinhar em fogo brando) and "using the microwave oven" (utilizar o forno de micro-ondas), respectively.

General meaning was adopted to achieve semantic (experiential) equivalence ${ }^{21,23}$ to the technique "roasting" which was back-translated as "cook on a flame (barbecue or grill)" by the first translator and as "baking flame (barbecue or grill)" by the second one, indicating that this was 'entirely altered' and 'much altered', respectively, when compared to the original version. In Brazil, both "baking" and "roasting" are recognized as the same cooking technique, meaning the application of dry heat to cook food (to cook without water). Considering that there is a custom of barbecuing on a grill over flame which is not called "grilling", as it is in the US, "roasting" was the preferred adaptation in this specific cooking practice and "baking" was referred to cooking in an oven.
All these changes up to stage III reflected some discrepancies in the back-translations, and tallies of degrees of change in items translated from the original version are listed in Table 1. When most of items in each measure were designated as 'much altered' or 'entirely altered' compared to their respective original versions, such as 9 of 12 cooking techniques from the SECT scale, they were revised by the dietitians' team before being discussed by the Expert Committee, evaluating general and referential meanings.

\section{What does fit for Brazil?}

From all amendments, the synthesis of the final Brazilian Portuguese version was generated, named as Questionário Brasileiro de Avaliação das Habilidades Culinárias e Alimentação Saudável - QBHC (Brazilian Cooking Skills and Healthy Eating Questionnaire - BCSQ) (Supplementary material). Forty-eight university students participated in the pre-test stage, where $62,0 \%$ were women ( $n=29)$, aged 20,6 ( $\pm 6,3 \mathrm{DP})$ years old, and distributed among academic majors including: Human Sciences $(\mathrm{n}=12)$, Health and Life Sciences $(n=7)$, Engineering $(n=29)$.

Participants' average time for filling out the questionnaire was $16,2( \pm 7,0 \mathrm{DP})$ minutes. Seventy-seven percent $(n=37)$ considered the BCSQ easy to fill out and $89.6 \%(n=43)$ found it sufficiently understandable. No respondent mentioned having difficulty neither with the amount of time allotted for completing the questionnaire nor with the number of questions.

Eight percent $(n=4)$ claimed it was somewhat difficult to comprehend, noting difficulty with specific cooking techniques. One participant found the questionnaire not sufficiently comprehensible, although they gave no reason for this. Only $2,1 \%(n=1)$ found it repetitive and 20,8\% $(n=10)$ considered it repetitive and hard to fill. Some also mentioned difficulty in understanding the term "confident".

For questions considered to be repetitive, few amendments were made to questions such as making some words uppercase (specifically in the $\mathrm{CB}$ and AAFV measures) to better highlight the differences among them. Some students reported that they did not know some of cooking terms and techniques, although they did not specify which of them were more problematic. These terms were then unchanged, given that students' cooking knowledge is one of the components to be evaluated by the questionnaire ${ }^{14}$, so it was not considered as a problem of translation. Also, 
many examples in parenthesis were provided to better illustrate the questions' meaning (Table 2).

All 48 participants also answered the questionnaire in the second time. Test-retest for the Availability and Accessibility of Fruits and Vegetables index (AAFV) showed weak agreement for item $1(0,33)$, which had the unusual expression in Brazil, "pure (100\%) fruit juice", differently from the US version, as discussed before (Table 2). Considering it was replaced by homemade fruit juice, including fruit pulp or readyto-drink whole fruit juice, the respondents may have looked at some of these options available in home differently in the first and second admin- istration. Other items showed moderate (items 4, 6 e 8), substantial (items 3, 5 e 7) and almost perfect (item 2) agreements.

For the remaining measures $(\mathrm{CA}, \mathrm{CB}, \mathrm{SEPC}$, SEC, SECT, SEFVS and CTT), correlation obtained from test-retest answers and internal consistency are showed on Table 2. All measures presented adequate internal consistency, except for Cooking Attitude (CA) and Behavior (CB) items. Intraclass correlation coefficient showed excellent significant correlations at test-retest for all measures, and satisfactory for Knowledge in Cooking Terms and Techniques Evaluation (CTT). Cooking knowledge can influence the

Table 1. Agreement between evaluations of Back-translations with the Original questionnaire items.

\begin{tabular}{|c|c|c|c|c|c|c|c|c|c|}
\hline \multirow[t]{2}{*}{ Measures $^{\star * *}$} & \multicolumn{4}{|c|}{$\begin{array}{l}\text { BT1 x OV evaluation } \\
\text { Changes from the Original Version } \\
\text { C }^{\star *}\end{array}$} & \multicolumn{4}{|c|}{$\begin{array}{l}\text { BT2 } x \text { OV evaluation }{ }^{\star} \\
\text { Changes from the Original Version } \\
\end{array}$} & \multirow{2}{*}{$\begin{array}{c}\begin{array}{c}\text { Agreement } \\
\text { of items (\%) }\end{array} \\
\text { Total }\end{array}$} \\
\hline & Not & Little & Much & Entirely & Not & Little & Much & Entirely & \\
\hline $\operatorname{AAFV}(\mathrm{n}=8)$ & 0 & 0 & 8 & 0 & 2 & 6 & 0 & 0 & 0 \\
\hline $\mathrm{CA}(\mathrm{n}=7)$ & 1 & 5 & 1 & 0 & 5 & 1 & 1 & 0 & $2(3,1)$ \\
\hline $\mathrm{CB}(\mathrm{n}=11)$ & 0 & 5 & 6 & 0 & 6 & 5 & 0 & 0 & $2(3,1)$ \\
\hline SEPC $(n=3)$ & 0 & 2 & 1 & 0 & 2 & 0 & 1 & 0 & 0 \\
\hline $\operatorname{SEC}(n=6)$ & 2 & 3 & 1 & 0 & 5 & 0 & 1 & 0 & $2(3,1)$ \\
\hline $\operatorname{SECT}(n=12)$ & 1 & 3 & 8 & 0 & 7 & 4 & 0 & 1 & $3(4,7)$ \\
\hline $\operatorname{SEFV}(\mathrm{n}=9)$ & 1 & 8 & 0 & 0 & 8 & 1 & 0 & 0 & $2(3,1)$ \\
\hline CTT $(\mathrm{n}=8)$ & 0 & 5 & 3 & 0 & 1 & 6 & 2 & 0 & $7(10,9)$ \\
\hline Total $(\mathrm{n}=64)$ & 5 & 31 & 28 & 0 & 36 & 23 & 5 & 1 & $18(28.1)$ \\
\hline Percentage (\%) & $(7,8)$ & $(48,4)$ & $(43,8)$ & & $(56,3)$ & $(35,9)$ & $(7,8)$ & $(1,6)$ & \\
\hline
\end{tabular}

${ }^{*} \mathrm{BT} 1=$ back-translation 1 ; BT2=Back-translation $2 ; \mathrm{OV}=$ original version. ${ }^{\star *}$ Not=not altered; Little $=$ little altered; Much $=$ much altered; Entirely=entirely altered. ${ }^{* *} \mathrm{AAFV}=$ Availability and Accessibility of Fruits and Vegetables Index; CA=Cooking Attitude; $\mathrm{CB}=$ Cooking Behavior; SEPC= Produce Consumption Self-Efficacy; SEC=Cooking Self-Efficacy; SECT=Self-Efficacy for Using Basic Cooking Techniques; SEFV= Self-Efficacy for Using Fruits, Vegetables and Seasonings; CTT=Knowledge of Cooking Terms and Techniques Evaluation.

Source: Jomori ${ }^{28}$.

Table 2. Internal consistency and intraclass correlation coefficients of Cooking Skills and Healthy Eating Questionnaire Measures.

\begin{tabular}{lrrrrr}
\hline \multicolumn{1}{c}{ Measures } & $\boldsymbol{\alpha}^{*}$ & ICC $^{* *}$ & \multicolumn{1}{c}{ IC 95\% } & p value $^{* * *}$ \\
\hline Cooking Atitude - CA & 0,29 & 0,29 & 0,83 & 0,95 & 0 \\
Cooking Behavior - CB & 0,68 & 0,80 & 0,64 & 0,89 & 0,000 \\
Self-efficacy in Produce Consumption - SEPC & $0,87^{\star}$ & 0,82 & 0,67 & 0,89 & 0,000 \\
Cooking Self-Efficacy - SEC & $0,80^{\star}$ & 0,87 & 0,77 & 0,93 & 0,000 \\
Self-Efficacy in Using Cooking Techniques - SECT & $0,87^{\star}$ & 0,89 & 0,81 & 0,94 & 0,000 \\
Self-Efficacy in Using Fruits, Vegetables and Seasonings - SEFVS & $0,87^{\star}$ & 0,29 & 0,83 & 0,95 & 0,000 \\
Knowledge in Cooking Terms and Techniques - CTT & NA & 0.69 & 0.42 & 0,83 & 0,000 \\
\hline ICC= intraclass correlation coefficient. NA=Not applicable. ${ }^{*}$ Cronbach $\alpha$ coefficient $>0.70 .{ }^{* *}$ ICC $<0.4=$ poor; $0.4 \leq$ ICC $<0.75=$ \\
satisfactory to good; ICC $\geq 0.75$ = excellent. ${ }^{* *}$ p $<0.05$
\end{tabular}


evaluation of self-efficacy in performing specific cooking techniques ${ }^{7}$. This stage presented reliability parameters to achieve measurement equivalence.

\section{Discussion}

Some adaptations in each stage were made according to the recommended sequence of stag$\mathrm{es}^{16-18}$. In the back-translation stage, the employed technique of independent comparison between original and back-translated item pairs by two evaluators ${ }^{18,24}$ allowed the team to identify translation problems, and in some cases, the reason for these problems was revealed.

The study demonstrates a $28 \%$ level of agreement between the two comparisons, which can be considered as low. Equivalences degrees between back-translated and original items from English language measurements (where $90-100 \%$ was unaltered, $70-<90 \%$ little altered, $50-<70 \%$ much altered, and $<50 \%$ entirely altered) were established regarding the number of items evaluated in each category ${ }^{24}$ although no parameter to indicate low or high agreement between evaluators for the back-translation stage is established.

Researchers refer to professional translators as generally concerned with idiomatic equivalences, which considers referential (denotative) meanings. Translators knowledgeable in the content of the questionnaire examine general (connotative) meaning regarding conceptual equivalence rather than idiomatic aspects ${ }^{18,29}$. However, in the present study, the professional English-native translator seemed less worried about idiomatic equivalences than the dietitian translator for most of the pairs of items and more about general meanings regarding the achievement of conceptual equivalence. On the other hand, the evaluation conducted by the translator that was knowledgeable in the subject matter seemed more sensitive to the fact that the small changes to the terms or expressions of the questionnaire could present barriers to level of participants understanding. It suggests that, many words and terms related to cooking skills subject area are not well established among specialists and defined in Brazi ${ }^{8,14}$ as in other countries ${ }^{1,5,6}$.

Back-translation has been considered a controversial stage in cross-cultural adaptation. Authors found that similar effects could be achieved either with a back-translation stage or with an evaluation by a committee of experts whose members speak both the source and tar- get languages or are experts in the content of the instrument ${ }^{29}$. This effect would be sufficient for reaching conceptual and measurement equivalences between the original and the translated instrument ${ }^{29,30}$.

Misgivings over the use of a back-translation stage ${ }^{29,30}$ were adequately addressed in the present study, because best terms and expressions for each Brazilian Portuguese version were defined during the discussion among the bilingual dietitians. Moreover, they were addressed later in stage IV until achieving semantic (experiential), conceptual and item equivalences with the original questionnaire. The back-translation stage was then important here to check these equivalences and employ quality control over the first stage $^{16,18,29}$.

In stage IV, the present study followed the recommendation of employing members with a variety of profiles, including in the debate translators, methodologist, experts on nutrition, and student participants (drawn from the target population) ${ }^{18,19,29}$. Therefore, it allowed to reach conceptual, item, semantic, experiential, and idiomatic equivalences between the instruments.

Results obtained from the pre-test stage also confirmed doubts that had emerged in the previous stages, such as several specific cooking techniques. Keeping these same terms from the original version resulted in similar psychometric properties of the instrument ${ }^{14}$.

The test-retest process in the present study indicated that the questionnaire evaluates the same parameters over time. Warmin et al..$^{5}$ has demonstrated the stability of the same measurement among university students, which all scales demonstrated acceptable correlations in different time points, except the CTT scale, as well as seen in the present study. The authors of this mentioned study had used the Pearson correlation's test while in the present study, Intraclass Correlation coefficient was used to evaluate the correlation of the same measures over time ${ }^{27}$. Moreover, for dichotomous variables, the Kappa coefficient is more recommended, as used in the present study ${ }^{31}$.

Regarding the items within the Availability and Accessibility of Fruits and Vegetables Index (AAFV) that showed weak to moderate agreement, it seemed that participants could have acquired or provided some fruits and vegetables at home between the test-retest intervals, as a phenomenon that changed over time, and as expected for low values in test-retest reliability ${ }^{27}$. Even so, the index has been well validated and used in 
the U.S. ${ }^{12}$, as well as showed good reliability and validity in Brazil ${ }^{16}$.

The low internal consistency found in the Cooking Attitude measure (CA) was similar to the one evaluated on a larger sample ${ }^{14}$, suggesting that many adapted words (e.g. "affordable" and "healthfully") or parts of the questionnaire could potentially lead to a low internal consistency. Likewise, some items in the Cooking Behavior measure (CB) showed low internal consistency, possibly since most of them have not been previously validated in the original version ${ }^{12,13}$. The items from this measure need more review to achieve conceptual equivalence to the original questionnaire, since they combined cooking behaviors related to using of fresh/basic ingredients with convenience foods as well as with leftovers and meals bought away from home seeming controversial to respondents ${ }^{14}$.

Among studies about cross-cultural adaptation of nutrition-related measurements, only the present, as well as Nowicka et al. ${ }^{20}$ and Camilleri et al. ${ }^{21}$ ones used a sample size above 30 participants as recommended to the pre-test stage. It can indicate that, these instruments are able to reach adequate psychometric proprieties ${ }^{18}$. Moreover, the present study was the only one which showed a diverse expert board in all stages as suggested by cross-cultural adaptation procedures, providing best equivalences to the original questionnaire 18,19,29. $^{2}$.

As key factor in the process of cross-cultural adaptation we can highlight the back-translated version's check made by the authors as well as the discussion that accompanied the back-translation stage. All these points contributed to make refinements in the following stage, the Expert Committees. Taken together, these procedures demonstrate that the subject of cooking skills requires multiple perspectives and thorough discussions.

\section{Conclusions}

The procedures adopted in this study made possible the adaptation of this questionnaire for Brazilian university students, providing lessons for further researches in different contexts, even this study was conducted in a single Brazilian university. The procedures described here can be considered adequate to specificities of nutrition-related instruments, reducing the lack of parameters for cross-cultural adaptation's steps.
To our knowledge, measurements addressing the subject of cooking skills are not available in many countries and this is the first time that the cooking skills' subject has been addressed based on the results of a process of cross-cultural adaptation of instruments.

The combination between the approaches of stages and evaluation by equivalences with the original questionnaire needs to be highlighted in this study, because it was not seen in any other study of nutrition-related measurements. It is important to strengthen that the measures about cooking self-efficacy (SEPC, SEC, SECT and SEFVS) resulted in coherent way to evaluate nutrition and culinary practices in Brazilian university students regarding their healthy food choices and cooking confidence. On the other hand, more psychometric proprieties evaluations for cooking attitudes (CA) and behaviors (CB) scales are needed after possible revisions are completed.

Furthermore, proposing guidelines and specific procedures for the cross-cultural adaptation process in further Nutrition-related questionnaires researches is quite timely. Currently, this area requires more standardized instruments and methods to conduct future much-needed studies in Brazil.

\section{Collaborators}

MM Jomori and RPC Proença conceptualized the study. MM Jomori and M Caraher drafted the first version and revised the manuscript for important intellectual content. MM Jomori and GL Bernardo collected the data. MM Jomori, PL Uggioni and ME Echevarria-Guanilo contributed to design the method and interpretation of the findings. ME Echevarria-Guanilo conducted the data analysis. GL Bernardo and M Condrasky contributed to some stages of the study. RPC Proença coordinated the study. All authors read and approved the final version of the manuscript. 


\section{Acknowledgments}

The authors thank students, Undergraduate courses' coordinators, collaborators and partnerships from Universidade Federal de Santa Catarina (UFSC), Universidade Federal de Alagoas (UFAL), Department of Food, Nutrition, and Packaging Sciences from Clemson University and Centre for Food Policy from City University London, the Coordenação de Aperfeiçoamento de Pessoal de Nivel Superior - CAPES and the Conselho Nacional de Desenvolvimento Científico e Tecnológico (CNPq).

\section{References}

1. Lang T, Caraher M, Dixon P, Carr-Hill R. Cooking skills and health. Education Authority: London; 1999.

2. United States Department of Agriculture (USDA). U.S. Department of Health and Human Services. Dietary Guidelines for Americans [document on the Internet]. [cited 2014 Jan 20]. 7th ed. Washington, DC: U.S. Government Printing Office; 2010. [about 112 p.]. Available from: https://health.gov/dietaryguidelines/ dga2010/dietaryguidelines2010.pdf

3. Brazil. Primary Health Care. Secretariat of Health Care Department. Ministry of Health of Brazil. Dietary Guidelines for the Brazilian Population [document on the Internet]. [accessed 2015 Jul 12]. 2nd ed. Brasília, DF: Ministry of Health of Brazil; 2014. [about 152 p.]. Available from: http://bvsms.saude.gov.br/ bvs/publicacoes/dietary_guidelines_brazilian_population.pdf

4. Wilson CK, Matthews JI, Seabrook JA, Dworatzek PDN. Self-reported food skills of university students. Appetite 2017; 108(1): 270-276.

5. Warmin A, Sharp J, Condrasky MD. Cooking with a Chef: a culinary nutrition program for college aged students. Top Clin Nutr 2012; 27(2): 164-173.

6. Lavelle, F, McGowan L, Spence M, Caraher M, Raats MM, Hollywood L, McDowell D, McCloat A, Mooney E, Dean M. Barriers and facilitators to cooking from 'scratch' using basic or raw ingredients: A qualitative interview study. Appetite 2016; 107(1): 383-391.

7. Caraher M, Dixon P, Lang T, Carr-Hill R. The state of cooking in England: The relationship of cooking skills to food choice. Br Food J 1999; 101(8):590-609.

8. Jomori MM, Vasconcelos FAG, Bernardo GL, Uggioni PL, Proença RPC. The concept of cooking skills: a review with contributions to the scientific debate. Rev Nutr 2018; 31(1):83-96.

9. Barton KL, Wrieden WL, Anderson AS. Validity and reliability of a short questionnaire for assessing the impact of cooking skills interventions. J Hum Nutr Diet 2011; 24(6):588-595.

10. Costa AIA. Conceptualization and measurement of personal norms regarding meal preparation. Int $J$ Consum Stud 2013; 37(6):596-604.

11. Miketinas D, Cater M, Bailey A, Craft B, Tuuri G. Exploratory and confirmatory factor analysis of the Adolescent Motivation to Cook Questionnaire: A Self-Determination Theory instrument. Appetite 2016; 105(1):527-533.

12. Michaud P. Development and evaluation of instruments to measure the effectiveness of a culinary and Nutrition education program [thesis]. Clemson (SC): Clemson University; 2007.

13. Condrasky MD, Williams JE, Catalano PM, Griffin SF. Development of psychosocial scales for evaluation the impact of a Culinary Nutrition Education program on cooking and healthful eating. J Nutr Educ Behav 2011; 43(6):511-516. 
14. Jomori MM, Proença RPC, Echevarria-Guanilo ME, Bernardo GL, Uggioni PL, Fernandes AC. Construct validity of Brazilian cooking skills and healthy eating questionnaire by the known-groups method. Br Food J 2017; 119(5):1003-1016.

15. Bernardo GL, Jomori MM, Fernandes AC, Colussi CF, Condrasky MD, Proença RPC. Nutrition and Culinary in the Kitchen Program: a randomized controlled intervention to promote cooking skills and healthy eating in university students - study protocol. Nutr J 2017; 16:83-95.

16. Guillemin F, Bombardier C, Beaton D. Cross-cultural adaptation of health-related quality of life measures: literature review and proposed guidelines. J Clin Epidemiol 1993; 46(12):1417-1432.

17. Beaton DE, Bombardier C, Guillemin F, Ferraz MB. Guidelines for the process of cross-cultural adaptation of self-report measures. Spine 2000; 25:31863191.

18. Reichenheim M, Moraes CLM. Operationalizing the cross-cultural adaptation of epidemiological measurement instruments. Rev Saude Publica 2007; 41(4):19.

19. Herdman M, Fox-Rushby J, Badia X. A model of equivalence in the cultural adaptation of HRQoL instruments: the universalist approach. Qual Life Res 1998; 7(4):323-335.

20. Nowicka P, Sorjonen K, Pietrobelli A, Flodmark CE, Faith MS. Parental feeding practices and associations with child weight status. Swedish validation of the Child Feeding Questionnaire finds parents of 4-year-olds less restrictive. Appetite 2014; 81(1):232-241.

21. Camilleri GM, Méjean C, Bellisle F, Andreeva VA, Sautron V, Hercberg S, Péneau S. Cross-cultural validity of the Intuitive Eating Scale-2. Psychometric evaluation in a sample of the general French population. Appetite 2015; 84(1): 34-42.

22. Meule A, Müller A, Gearhardt AN, Seligman HK. German version of the Yale Food Addiction Scale 2.0: Prevalence and correlates of 'food addiction' in students and obese individuals, Appetite 2017; 115(1):54-61.

23. Perneger TV, Courvoisier DS, Hudelson PM, Gaye$\mathrm{t}$-Ageron, A. Sample size for pre-tests of questionnaires. Qual Life Res 2015; 24(1):147-151.

24. Moraes CL, Hasselmann MH, Reichenheim ME. Portuguese-language cross-cultural adaptation of the Revised Conflict Tactics Scales (CTS2), an instrument used to identify violence in couples. Cad Saude Publica 2002; 18(1):163-176.

25. Fink A, Kosecoff J, Chassin M, Brook RH. Consensus methods: characteristics and guidelines for use. $A m \mathrm{~J}$ Public Health 1984; 74(4):979-983.

26. Streiner DL, Norman GR, Cairney J. Health Measurement Scales - A Practical Guide to their Development and use. $5^{\text {th }}$ ed. New York: Oxford University Press; 2015.
27. Bland JM, Altman DG. A note on the use of the intraclass correlation coefficient in the evaluation of agreement between two methods of measurement. Comput Biol Med 1990; 20(5):337-340.

28. Jomori MM. Adaptação transcultural e validacão de um instrumento de identificação de habilidades culinárias e alimentação saudável em estudantes ingressantes de uma universidade brasileira [dissertation]. Florianópolis, SC: Universidade Federal de Santa Catarina, 2017.

29. Epstein J, Osborned RH, Elsworthd GR, Beaton DE Guillemin F. Cross-cultural adaptation of the Health Education Impact Questionnaire: experimental study showed expert committee, not back-translation, added value. J Clin Epidemiol 2015; 68(4):360-369.

30. Epstein J, Santo RM, Guillemin F. A review of guidelines for cross-cultural adaptation of questionnaires could not bring out a consensus. J Clin Epidemiol 2015; 68(4):435-441.

31. Landis JR, Koch GG. A one-way components of variance model for categorical data. Biometrics 1997; 33(4):671-679.

Article submitted 31/10/2018

Approved 19/09/2019

Final version submitted 21/09/2019

Chief Editors: Romeu Gomes, Antônio Augusto Moura da Silva 
